\title{
Coffee and hepatocellular carcinoma: epidemiologic evidence and biologic mechanisms
}

\author{
Filippo Pelizzaro, Romilda Cardin, Anna Sartori, Angela Imondi, Barbara Penzo, Fabio Farinati \\ Department of Surgery, Oncology and Gastroenterology, Gastroenterology Unit, University of Padova, Padova 35128, Italy.
}

Correspondence to: Prof. Fabio Farinati, Department of Surgery, Oncology and Gastroenterology, Gastroenterology Unit, University of Padova, Via Giustiniani 2, Padova 35128, Italy. E-mail: fabio.farinati@unipd.it

\begin{abstract}
How to cite this article: Pelizzaro F, Cardin R, Sartori A, Imondi A, Penzo B, Farinati F. Coffee and hepatocellular carcinoma: epidemiologic evidence and biologic mechanisms. Hepatoma Res 2021;7:29. https://dx.doi.org/10.20517/2394-5079.2020.148
\end{abstract}

Received: 17 Nov 2020 First Decision: 4 Jan 2021 Revised: 12 Jan 2021 Accepted: 2 Feb 2021 Available online: 9 Apr 2021

Academic Editors: Manuela Merli, Yong-Bing Xiang Copy Editor: Xi-Jun Chen Production Editor: Yue-Yue Zhang

\begin{abstract}
Coffee is one of the most widely consumed beverages worldwide. It is a complex chemical mixture composed of thousands of physiologically active compounds, including caffeine, chlorogenic acid, and diterpenes (cafestol and kahweol). Recently, coffee has emerged as a beverage with various health benefits, in particular in liver disease. Several epidemiological and observational studies demonstrated an inverse association between coffee consumption and primary liver cancer risk. The biological mechanisms underlying the hepatoprotective effect of coffee are still not completely understood. This article reviews the current available literature about the association between coffee consumption and hepatocellular carcinoma risk and the proposed mechanisms by which coffee exerts its chemopreventive properties.
\end{abstract}

Keywords: Coffee, primary liver cancer, hepatocellular carcinoma, oxidative stress

\section{INTRODUCTION}

Coffee is one of the most commonly consumed beverages worldwide, with approximately 500 billion cups drunk every year globally ${ }^{[1]}$. Its widespread use is not only related to its aroma and flavor but also to its stimulating properties.

Being coffee a rich source of antioxidants and other bioactive compounds ${ }^{[1]}$, its long-term consumption has been associated with various health benefits, including a decreased risk of type 2 diabetes ${ }^{[2]}, \operatorname{stroke}^{[3-5]}$, symptomatic gallstone disease $e^{[6]}$, Parkinson's disease ${ }^{[7]}$, and cardiovascular disease ${ }^{[8]}$. Overall, coffee intake 
has been inversely associated with all-cause and disease-specific mortality ${ }^{[9]}$.

Over the past 20 years, several studies reported a beneficial effect of coffee on liver health. Its consumption has been associated with reduced liver enzymes ${ }^{[10-12]}$, decreased incidence of chronic liver disease ${ }^{[13,14]}$, improved response to retreatment in patients with chronic HCV infection ${ }^{[15]}$, and lower risk of cirrhosis $^{[16,17]}$. Coffee is protective against the development and progression of non-alcoholic fatty liver disease (NAFLD) $)^{[18,19]}$. Patients with alcoholic and non-alcoholic chronic liver disease who habitually consume coffee have a decreased mortality risk ${ }^{[10,20,21]}$. In addition, a reduced incidence of liver cancer has been repeatedly reported in coffee drinkers ${ }^{[2-31]}$. The biological plausibility of this inverse association found in observational studies has been confirmed by experimental data ${ }^{[32,33]}$.

Primary liver cancer is the sixth most common cancer and the fourth leading cause of cancer-related death globally, with an incidence of 841,000 new cases/year and a mortality of 782,000 deaths/year in $2018^{[34]}$. Hepatocellular carcinoma (HCC) is the most frequent primary liver malignancy, constituting a major global health problem ${ }^{[35]}$. HCC usually develops on a background of inflammation and oxidative stress, which is elicited by several etiologic factors, such as chronic HBV or HCV infections, excessive alcohol consumption, aflatoxin exposure, and NAFLD development ${ }^{[36]}$.

In this paper, we review the current available evidence in the literature linking coffee consumption to decreased HCC risk and explore the possible biological mechanisms underlying the protective effect of coffee.

\section{WHAT ARE WE TALKING ABOUT WHEN WE SAY COFFEE?}

Coffee contains more than one thousand physiologically active compounds, the concentrations of which can be influenced not only by species, variety of plant, and cultivation method but also by preparation processes (e.g., roasting, blending, and brewing) ${ }^{[37,38]}$. The main water-soluble constituents of coffee are phenolic polymers $(8 \%)$, polysaccharides $(6 \%)$, chlorogenic acids $(4 \%)$, minerals $(3 \%)$, water $(2 \%)$, and caffeine $(1 \%)^{[38]}$. In addition, coffee contains a lipid fraction made of triacylglycerols, tocopherols, fatty acids, and diterpenes (mainly, cafestol and kahweol ${ }^{[39]}$. Caffeine is considered the major active ingredient of coffe $^{[40,41]}$, but several other components (e.g., chlorogenic acid, cafestol, and kahweol) have strong antioxidant properties ${ }^{[2,43]}$.

Among the most commonly used methods to prepare coffee there are: (1) filtration, in which hot water is passed through ground coffee beans kept on a filter; (2) boiling, in which ground coffee beans in water are brought to boil (as in Turkish coffee); and (3) forced pressurization, in which water is forced under pressure through ground coffee (as in espresso). The methods used in the preparation are relevant because they influence the chemical composition of coffee. Filtered coffee contains negligible amount of diterpenes (cafestol and kahweol are removed by paper filters), but filtration better preserves chlorogenic acid than forced pressurization ${ }^{[4]}$. Diterpenes levels are also affected by brewing strength (i.e., the concentration of coffee grounds per liter of water) ${ }^{[45]}$. Compared to filtered coffee, espresso has higher concentration of caffeine ${ }^{[40,46]}$, but it is typically consumed in much smaller quantities. Beyond the brewing method, the addition of milk or cream to coffee could also potentially affect the bioavailability of its compounds $s^{[4]]}$.

\section{COFFEE AND THE RISK OF HEPATOCELLULAR CARCINOMA}

A recent large population-based cohort study, aimed at investigating the association between coffee intake and digestive tract cancer incidence, reported a risk reduction in coffee consumers only for HCC [adjusted hazard ratio $(\mathrm{HR})=0.5,95 \% \mathrm{CI}: 0.29-0.87$, compared to non-drinkers $]^{[48]}$. These results confirm several 
previous reports of an inverse relationship between coffee consumption and risk of HCC [Table 1].

The first two case-control studies investigating the effect of coffee consumption on HCC incidence failed to demonstrate a significant decrease in primary liver cancer risk among coffee drinkers ${ }^{[4,50]}$. However, when data included in these two studies were reanalyzed by Gallus et al. ${ }^{[22]}$ in a follow-up study, an odds ratio (OR) for the risk of develop HCC of 0.7 (95\%CI: 0.5-1.0) was demonstrated in subjects with an intake of $\geq 3$ cups/day compared to non-drinkers. Other more recent case-control studies confirmed the reduction of HCC risk among coffee consumers, with a dose-response relationship ${ }^{[2,51,52]}$. In particular, Tanaka et al. ${ }^{[52]}$ investigated the effect of coffee intake in the risk of HCC using three different control groups [healthy subjects, hospital controls, and patients with chronic liver disease (CLD)]. A significant risk reduction was observed in comparison to all the three control groups when coffee intake in the previous 1-2 years was considered, but only with respect to community and CLD controls when the last 10 years consumption were assessed.

In addition to these case-control studies, several prospective cohorts confirmed the reduction in incidence of liver cancer among coffee drinkers. The multivariate-adjusted relative risk (RR) in a Japanese pooled analysis of two cohorts (Shimazu et al. ${ }^{[24]}$ ) was 0.58 (95\%CI: 0.36-0.96) in patients consuming one or more cups/day, compared to subjects who never consume coffee. Inoue et al. ${ }^{[25]}$ showed that subjects who drank coffee almost every day had a 51\% lower HCC risk than those who almost never drank (HR $=0.49,95 \% \mathrm{CI}$ : 0.36-0.66), and the risk was inversely proportional to the amount of coffee intake (compared to no coffee intake, $\mathrm{HR}=0.52,0.48$, and 0.24 for $1-2,3-4$, and $\geq 5$ cups/day, respectively; $P_{\text {trend }} \leq 0.001$ ). In a Singapore cohort, the risk of HCC in patients consuming $\geq 3$ cups/day, compared to non-drinkers, was decreased by $44 \%(\mathrm{HR}=0.56,95 \% \mathrm{CI}: 0.31-1.0, P=0.049)$, after adjustment for many variables including tea consumption ${ }^{[53]}$. A similar inverse association was observed between HCC risk and the amount of caffeine consumed, and the further adjustment for HBV and/or HCV serology did not alter these results.

Several prospective cohorts from United States and Europe further confirmed this inverse association. Petrick et al. ${ }^{[27]}$ pooled together nine United States cohorts (the Liver Cancer Pooling Project) finding that subjects consuming at least three cups of coffee per day had a $27 \%$ lower risk of HCC (HR $=0.73,95 \%$ CI: 0.53-0.99), with an inverse dose-response relationship $\left(\mathrm{HR}_{\text {cups/day }}=0.90,95 \% \mathrm{CI}: 0.85-0.94\right)$. The risk reduction for every cup of coffee consumed per day was quite similar in males and females $[\mathrm{HR}=0.90$ (95\%CI: 0.86-0.96) $P_{\text {trend }}=0.0004$ for males and HR $=0.87$ (95\%CI: 0.79-0.96) $P_{\text {trend }}=0.004$ for females]. A second study from the United States, performed in the Multiethnic cohort, demonstrated that, compared with non-coffee drinkers, individuals who consumed 1, 2-3, and $\geq 4$ cups of coffee per day had a $13 \%(\mathrm{RR}=$ $0.87,95 \% \mathrm{CI}: 0.67-1.11)$, a $38 \%(\mathrm{RR}=0.62,95 \% \mathrm{CI}: 0.46-0.84)$, and $41 \%(\mathrm{RR}=0.59,95 \% \mathrm{CI}: 0.35-0.99)$ reduction in risk of HCC, respectively ${ }^{[54]}$.

These data were confirmed also in Europe. In a prospective study conducted in Finland by $\mathrm{Hu}$ et al. ${ }^{[26]}$, the multivariate-adjusted HRs of liver cancer in subjects who drank 0-1, 2-3, 4-5, 6-7, and $\geq 8$ cups/day were 1.0 (reference), 0.66, 0.44, 0.38, and 0.32, respectively $\left(P_{\text {trend }}=0.003\right)$. Note that, in this study, the definition of "liver cancer" included not only HCC but also cholangiocarcinoma, adenocarcinoma, and unspecified primary liver cancer. In a cohort of male smokers, Lai et al. ${ }^{[55]}$ obtained comparable results (18\% reduction in liver cancer risk for every other cup of coffee drunk per day, RR per cup per day $=0.82,95 \%$ CI: 0.73 0.93), even when only HCC patients were considered.

Two studies from the European Prospective Investigation into Cancer and Nutrition (EPIC) cohort further confirmed the inverse association between coffee drinking and reduced liver cancer risk ${ }^{[56,57]}$. In particular, 
Table 1. Studies evaluating the association between coffee consumption and primary liver cancer incidence and mortality

\begin{tabular}{|c|c|c|c|c|c|c|}
\hline Ref. & Year & Country & Design & $\begin{array}{l}\mathbf{N} \text { of } \\
\text { cases }\end{array}$ & $\begin{array}{l}N \text { of } \\
\text { controls/size of } \\
\text { cohort }\end{array}$ & Results \\
\hline La Vecchia et al. ${ }^{\mathrm{a}[49]}$ & 1989 & Italy & Case-control & 151 & 1,944 & $\begin{array}{l}\text { No significant association between coffee } \\
\text { and liver cancer }\end{array}$ \\
\hline Kuper et al. ${ }^{\mathrm{a}[50]}$ & 2000 & Greece & Case-control & 333 & 360 & $\begin{array}{l}\text { Coffee not positively associated with } \mathrm{HCC} \\
\text { risk }\end{array}$ \\
\hline Gallus et al..$^{[22]}$ & 2002 & Italy & Case-control & 834 & 1,912 & $\begin{array}{l}\text { Inverse association between coffee } \\
\text { drinking and liver cancer incidence }\end{array}$ \\
\hline Inoue et al. ${ }^{[25]}$ & 2005 & Japan & $\begin{array}{l}\text { Prospective } \\
\text { cohort }\end{array}$ & 334 & 90,452 & $\begin{array}{l}\text { Coffee drinking associated with a reduced } \\
\text { risk of } \mathrm{HCC}\end{array}$ \\
\hline Gelatti et al. ${ }^{[23]}$ & 2005 & Italy & Case-control & 250 & 500 & $\begin{array}{l}\text { Coffee intake inversely associated with } \\
\text { HCC, with a dose-effect relationship } \\
\text { regardless of its etiology (alcohol, HCV, } \\
\text { HBV) }\end{array}$ \\
\hline Kurozawa et al. ${ }^{[58]}$ & 2005 & Japan & $\begin{array}{l}\text { Prospective } \\
\text { cohort }\end{array}$ & 401 & 110,688 & $\begin{array}{l}\text { Inverse association between coffee and } \\
\mathrm{HCC} \text { mortality }\end{array}$ \\
\hline Shimazu et al. ${ }^{[24]}$ & 2005 & Japan & $\begin{array}{l}\text { Prospective } \\
\text { cohort } 1 \\
\text { Prospective } \\
\text { cohort } 2\end{array}$ & $\begin{array}{l}70 \\
47\end{array}$ & $\begin{array}{l}22,404 \\
38,703\end{array}$ & $\begin{array}{l}\text { Coffee consumption decreases the risk of } \\
\text { liver cancer }\end{array}$ \\
\hline Ohfuji et al. ${ }^{[60]}$ & 2006 & Japan & Case-control & 73 & 253 & $\begin{array}{l}\text { Coffee may be a protective factor among } \\
\text { patients with chronic HCV-related liver } \\
\text { disease }\end{array}$ \\
\hline Montella et al. ${ }^{[51]}$ & 2007 & Italy & Case-control & 185 & 412 & $\begin{array}{l}\text { Inverse relation between caffeinated } \\
\text { coffee consumption and HCC risk }\end{array}$ \\
\hline Wakai et al. ${ }^{[59]}$ & 2007 & Japan & Case-control & 96 & $\begin{array}{l}420\left(\mathrm{HCV}^{+}\right) \\
3,024\left(\mathrm{HCV}^{-}\right)\end{array}$ & $\begin{array}{l}\text { Coffee associated with a decreased HCC } \\
\text { mortality in all subjects and in those } \\
\text { infected with HCV }\end{array}$ \\
\hline Tanaka et al. ${ }^{[52]}$ & 2007 & Japan & Case-control & 209 & $\begin{array}{l}1,308 \\
\text { (Community) } \\
275 \text { (Hospital) } \\
381 \text { (CLD) }\end{array}$ & $\begin{array}{l}\text { Dose-dependent inverse association } \\
\text { between coffee consumption and HCC } \\
\text { risk, in particular in community and CLD } \\
\text { controls }\end{array}$ \\
\hline Hu et al. ${ }^{[26]}$ & 2008 & Finland & $\begin{array}{l}\text { Prospective } \\
\text { cohort }\end{array}$ & 128 & 60,323 & $\begin{array}{l}\text { Significant dose-dependent inverse } \\
\text { association between coffee drinking and } \\
\text { the risk of primary liver cancer }\end{array}$ \\
\hline Inoue et al. ${ }^{\mathrm{b}[69]}$ & 2009 & Japan & $\begin{array}{l}\text { Prospective } \\
\text { cohort }\end{array}$ & 110 & 18,815 & $\begin{array}{l}\text { Coffee consumption may reduce the risk } \\
\text { of liver cancer regardless of } \mathrm{HCV} \text { and } \mathrm{HBV} \\
\text { infection status }\end{array}$ \\
\hline Johnson et al. $^{[53]}$ & 2011 & China & $\begin{array}{l}\text { Prospective } \\
\text { cohort }\end{array}$ & 362 & 61,321 & $\begin{array}{l}\text { Coffee and caffeine consumption inversely } \\
\text { associated with the risk of HCC }\end{array}$ \\
\hline Leung et al. ${ }^{[61]}$ & 2011 & $\begin{array}{l}\text { Hong } \\
\text { Kong }\end{array}$ & Case-control & 109 & 125 & $\begin{array}{l}\text { Coffee reduces the risk of } \mathrm{HCC} \text { in } \mathrm{HBV} \\
\text { chronic carriers }\end{array}$ \\
\hline Jang et al. ${ }^{[61]}$ & 2013 & Korea & Case-control & 258 & $\begin{array}{l}480 \text { (Healthy) } \\
626 \text { (CLD) }\end{array}$ & $\begin{array}{l}\text { Coffee associated with a reduced risk of } \\
\text { HCC in subjects with and without CLD; } \\
\text { protective effect of coffee not proven in } \\
\text { HBV patients }\end{array}$ \\
\hline Lai et al. $^{[55]}$ & 2013 & Finland & $\begin{array}{l}\text { Prospective } \\
\text { cohort }\end{array}$ & 194 & 27,037 & $\begin{array}{l}\text { Lower risk of liver cancer and mortality } \\
\text { from CLD in male smokers who consumed } \\
\text { more coffee }\end{array}$ \\
\hline Petrick et al. ${ }^{[27]}$ & 2015 & $\begin{array}{l}\text { United } \\
\text { States }\end{array}$ & $\begin{array}{l}9 \text { US cohorts } \\
\text { pooled together }\end{array}$ & 860 & $1,212,893$ & $\begin{array}{l}\text { Inverse association between coffee } \\
\text { consumption and HCC risk; stronger } \\
\text { association observed for women }\end{array}$ \\
\hline Setiawan et al. ${ }^{[54]}$ & 2015 & $\begin{array}{l}\text { United } \\
\text { States }\end{array}$ & $\begin{array}{l}\text { Prospective } \\
\text { cohort }\end{array}$ & 451 & 162,022 & $\begin{array}{l}\text { Coffee associated, in dose-dependent } \\
\text { manner, with lower risk of incident HCC } \\
\text { and mortality from CLD }\end{array}$ \\
\hline Aleksandrova et al. ${ }^{[57]}$ & 2015 & Europe $^{c}$ & Case-control & 125 & 250 & $\begin{array}{l}\text { Coffee intake associated with a lower risk } \\
\text { of } \mathrm{HCC}\end{array}$ \\
\hline Bamia et al. ${ }^{[56]}$ & 2015 & Europe $^{c}$ & $\begin{array}{l}\text { Prospective } \\
\text { cohort }\end{array}$ & 201 & 486,799 & $\begin{array}{l}\text { Inverse association between coffee } \\
\text { consumption, in a dose-dependent } \\
\text { pattern, and HCC risk }\end{array}$ \\
\hline Tran et al. ${ }^{[48]}$ & 2019 & United & Prospective & 88 & 471,779 & Inverse association between coffee \\
\hline
\end{tabular}


${ }^{a}$ These data were reanalyzed by Gallus et al. ${ }^{[22]}$; bthis study duplicated data previously presented (Inoue et al. $\left.{ }^{[25]}, 2005\right)$; ${ }^{c}$ Denmark, France, Germany, Greece, Italy, Netherlands, Norway, Spain, Sweden, and the United Kingdom. HBV: Hepatitis B virus; HCV: hepatitis C virus; HCC: hepatocellular carcinoma; CLD: chronic liver disease; US: United States.

Bamia et al. ${ }^{[56]}$ found that, compared to those with minimal or no consumption of coffee, participants in the highest quintile of coffee intake had a $72 \%$ reduction in the HCC risk $(\mathrm{HR}=0.28,95 \% \mathrm{CI}: 0.16-0.50)$.

Similarly, the effect of coffee was confirmed in Japan. Data deriving from the Japan Collaborative Cohort Study for Evaluation of Cancer Risk (JACC) demonstrated that coffee consumption reduces liver cancer mortality ${ }^{[58,59]}$. In a large cohort study, Kurozawa et al. ${ }^{[58]}$ found a $50 \%$ reduction in risk of death for HCC (95\%CI: 0.31-0.79) in coffee drinkers compared with non-drinkers. This mortality reduction was similar to that found in the nested case-control study by Wakai et al. ${ }^{[59]}$ (taking coffee non-drinkers as reference group, the multivariate-adjusted OR in drinkers of $\geq 1$ cup/day was $0.49,95 \% \mathrm{CI}$ : 0.25-0.96). The analysis restricted to HCV-positive patients confirmed the result achieved in all patients $(\mathrm{OR}=0.31,95 \% \mathrm{CI}$ : 0.11-0.85), while, despite the OR below unit for daily coffee drinkers, the statistical significance was not obtained in HCVnegative group. This study supported the previous findings by Gelatti et al. ${ }^{[23]}$, Ohfuji et al. ${ }^{[00]}$, and Inoue et al. ${ }^{[25]}$ who demonstrated an inverse association between coffee drinking and HCC risk in HCV-positive patients. However, not all studies are concordant on that point ${ }^{[51]}$.

On the other hand, when patients with HBV infection are considered, available data on the protective role of coffee on HCC incidence are conflicting. Using as control groups healthy subjects and CLD patients, Jang et al.$^{[61]}$ found that high lifetime coffee consumption (> 20,000 cups) lowered HCC risk by $44 \%$ (OR $=0.56$, 95\%CI: 0.33-0.95) and 45\% (OR = 0.55, 95\%CI: 0.36-0.85), respectively, regardless of etiology. However, in the $519 \mathrm{HBV}$ patients included in this study, coffee drinking was not an independent protective factor against HCC $(\mathrm{OR}=0.64,95 \% \mathrm{CI}$ : 0.36-1.14, $P=0.129)$. By contrast, another case-control study conducted in HBV chronic carriers demonstrated that coffee drinking reduced HCC risk by almost half $(\mathrm{OR}=0.54$, 95\%CI: 0.30-0.97), with a dose-response effect (subjects drinking $\geq 4$ coffee/week had a risk reduction of almost $60 \%$ compared to those without coffee-drinking habit; $\left.P_{\text {trend }}=0.02\right)^{[62]}$. The many epidemiological data produced have been included in several metanalysis over the last 15 years, all confirming the inverse association between coffee consumption and HCC risk ${ }^{[28-31,63-68]}$ [Table 2].

\section{Are all types of coffee equally protective against HCC?}

Interestingly, only filtered coffee (one of the main types of coffee consumed in United States) has been significantly correlated with reduction in liver fibrosis, cirrhosis, and HCC; neither espresso (widely consumed in Europe) nor boiled coffee (i.e., Turkish coffee) has been negatively correlated with fibrosis $\operatorname{progression}^{[40]}$. Filtered coffee, but not espresso, was independently correlated with liver fibrosis in severe obese women with $\mathrm{NAFLD}^{[44]}$. Considering that fructose has been associated with the development of fibrosis in non-alcoholic steatohepatitis (NASH) ${ }^{[70]}$, in this study, the authors postulated that the lack of beneficial effect of espresso was probably due to the addition of sucrose (composed of glucose and fructose) to coffee. Moreover, brewing methods influence the chemical composition of coffee, and this may explain why different types of coffee are not equally beneficial on liver health.

The early studies evaluating the association between coffee consumption and HCC did not consider the type of coffee consumed ${ }^{[22,24,25,52,58,59,68]}$. Firstly, Huet al. ${ }^{[26]}$ reported a liver cancer risk reduction irrespective of the coffee preparation method (inverse trend in risk in both filtered and boiled coffee drinkers). A second 
Table 2. Metanalyses evaluating the association between coffee consumption and HCC risk

\begin{tabular}{|c|c|c|c|c|}
\hline Ref. & Year & $\begin{array}{l}\text { Studies } \\
\text { included }\end{array}$ & $\begin{array}{l}\text { RR or OR } \\
(95 \% \mathrm{Cl})\end{array}$ & Notes \\
\hline Larsson et al. ${ }^{[28]}$ & 2007 & $\begin{array}{l}5 \text { case-control } \\
4 \text { prospective } \\
\text { cohorts }\end{array}$ & $\begin{array}{l}0.57(0.49- \\
0.67)\end{array}$ & RR for an increment of 2 cups of coffee per day \\
\hline Bravi et al. ${ }^{[29]}$ & 2007 & $\begin{array}{l}7 \text { case-controla } \\
3 \text { prospective } \\
\text { cohorts }\end{array}$ & $\begin{array}{l}0.59(0.49- \\
0.72)\end{array}$ & $\begin{array}{l}\text { RR for coffee drinkers for an increment of } 1 \text { cup per day of coffee the } \\
\text { RR was } 0.77(0.72-0.82)\end{array}$ \\
\hline Bravi et al. ${ }^{[63]}$ & 2009 & $\begin{array}{l}7 \text { case-controla } \\
7 \text { prospective } \\
\text { cohorts }^{6}\end{array}$ & $\begin{array}{l}0.57(0.49- \\
0.67)\end{array}$ & RR for coffee drinkers vs. non-drinkers \\
\hline Sang et al. ${ }^{[64]}$ & 2013 & $\begin{array}{l}9 \text { case-control } \\
6 \text { prospective }^{\text {cohorts }}{ }^{\mathrm{b}}\end{array}$ & $\begin{array}{l}0.50(0.42- \\
0.59)\end{array}$ & OR for high drinkers compared to no/almost never drinkers \\
\hline Bravi et al. ${ }^{[30]}$ & 2013 & $\begin{array}{l}7 \text { case-controla } \\
7 \text { prospective } \\
\text { cohorts }^{\text {b }}\end{array}$ & $\begin{array}{l}0.60(0.50- \\
0.71)\end{array}$ & $\begin{array}{l}\text { RR for coffee drinkers vs. non-drinkers; for an increment of } 1 \text { cup per } \\
\text { day the RR was } 0.80(0.77 .0 .84)\end{array}$ \\
\hline Bai et al. ${ }^{[65]}$ & 2016 & $\begin{array}{l}8 \text { case-control } \\
3 \text { prospective } \\
\text { cohorts }\end{array}$ & $\begin{array}{l}0.49(0.46- \\
0.52)\end{array}$ & $\begin{array}{l}\text { OR for coffee drinkers compared to non-drinkers. Only studies in } \\
\text { which the outcome was HCC were included in the metanalysis }\end{array}$ \\
\hline Yu et al. ${ }^{[66]}$ & 2016 & $\begin{array}{l}10 \text { prospective } \\
\text { cohorts }^{6}\end{array}$ & $\begin{array}{l}0.55(0.44- \\
0.67)\end{array}$ & $\begin{array}{l}\text { RR of liver cancer for highest vs. lowest ( } 0-1 \text { cup/day) coffee } \\
\text { consumption; an inverse association between coffee consumption } \\
\text { (cups/day) and liver cancer risk }\end{array}$ \\
\hline Bravi et al..$^{[31]}$ & 2017 & $\begin{array}{l}11 \text { prospective } \\
\text { cohorts }^{\mathrm{b}}\end{array}$ & $\begin{array}{l}0.66(0.55- \\
0.78)\end{array}$ & $\begin{array}{l}\text { RR for coffee drinkers compared to non-drinkers; for an increment of } 1 \\
\text { cup per day of coffee the RR was } 0.85(0.81-0.90)\end{array}$ \\
\hline Kennedy et al. ${ }^{[67]}$ & 2017 & $\begin{array}{l}7 \text { case-control } \\
9 \text { prospective } \\
\text { cohorts }\end{array}$ & $\begin{array}{l}0.65(0.59- \\
0.72)\end{array}$ & RR of HCC for an increment of 2 cups of coffee per day \\
\hline Bhurwal et al. ${ }^{[68]}$ & 2020 & $\begin{array}{l}8 \text { case-controla } \\
12 \text { prospective } \\
\text { cohorts }\end{array}$ & $\begin{array}{l}0.69(0.56- \\
0.85)\end{array}$ & $\begin{array}{l}\text { RR of primary liver cancer for coffee consumers compared to non- } \\
\text { drinkers; drinking } \geq 3 \text { cups } / \text { day significantly decreases the risk of liver } \\
\text { cancer (RR }=0.51,95 \% \mathrm{Cl}: 0.38-0.69)\end{array}$ \\
\hline
\end{tabular}

${ }^{a}$ One case-control study (Gallus et al. ${ }^{[22]}$, 2002) included data from two previous case-control studies (La Vecchia et al. ${ }^{[49]}, 1989 ;$ Kuper et al. ${ }^{[50]}$, 2000) that were considered separately; ${ }^{b}$ One prospective study (Shimazu et al. ${ }^{[24]}$,2005) presented data from two cohorts that were considered separately. RR: Relative risk; OR: odds ratio; HCC: hepatocellular carcinoma.

large prospective Finnish study ${ }^{[55]}$ confirmed that both filtered and boiled coffee were inversely associated with liver cancer, although the risk reduction was higher for the former ( $\mathrm{RR}=0.82,95 \% \mathrm{CI}$ : 0.69-0.98). In a more recent study, the risk reduction in different brewed coffee ranged from $49 \%$ to 53\%, with instant coffee providing the highest protection against liver cancer (adjusted $\mathrm{HR}=0.51,95 \% \mathrm{CI}$ : 0.28-0.93); however, there was no evidence of a difference in the risk of HCC by type of coffee $(P=0.53)^{[48]}$.

Although non-coffee caffeinated sources (i.e., tea) have not been associated with hepatoprotective effects $^{[12,16]}$, a considerable chemopreventive role of caffeine could not be excluded ${ }^{[40]}$. Indeed, all studies addressing the question about the role of decaffeinated coffee in reducing the risk of HCC gave the same answer: decaffeinated coffee is not protective against liver cancer ${ }^{[27,51,53,54,56]}$. Petricket al ${ }^{[27]}$ demonstrated that, compared to non-drinkers, subjects consuming decaffeinated coffee had an HR for the HCC development of 1.16 (95\%CI: 0.88-1.53). In the US Multiethnic cohort, compared to patients who never drink decaffeinated coffee, those drinking one cup/day had a RR $=0.93$ (95\%CI: 0.75-1.14), quite similar to that of patients drinking $\geq 2 \mathrm{cups} /$ day $(\mathrm{RR}=0.96,95 \% \mathrm{CI} \text { : } 0.62-1.50)^{[54]}$. The inverse association between decaffeinated coffee and HCC risk was considerably weaker compared to caffeinated coffee and statistically nonsignificant in the study of Bamia et al. ${ }^{[56]}$. Despite caffeine having a central role in the chemoprevention of HCC, it is likely that not one coffee compound in particular, but the synergistic effect of the multiple coffee constituents, provides the described benefits to liver health. 


\section{Limitations in the interpretation of epidemiological studies}

There are numerous limitations when interpreting the studies evaluating the health benefit of drinking coffee. All observational (cohort and case-control studies) are subject to different sources of bias and confounding, the main one being the difficulty in establishing whether the inverse relationship between coffee consumption and liver cancer risk is causal. This inverse relation may simply be due to the fact that subjects with digestive disorders, chronic liver diseases, and cirrhosis reduce spontaneously their coffee consumption, because of impairment in caffeine metabolism (reverse causation bias) ${ }^{[71,72]}$. Indeed, systemic caffeine clearance correlates with liver disfunction, and its measurement, even in saliva, has been suggested as a non-invasive test to evaluate residual liver function in patients with chronic liver disease ${ }^{[73-78]}$. Moreover, in compensated cirrhotics, some authors have reported that the total overnight salivary caffeine assessment could be useful in distinguishing between viral and metabolic etiology ${ }^{[77]}$.

The reverse causation bias could not be excluded in observational studies, even though obviously it is higher in retrospective case-control ${ }^{[22,23,51,52,59-61,68]}$ than prospective cohort studies, which evaluate the exposure of interest years before the liver cancer occurrence ${ }^{[24-27,53-56,58]}$. Several attempts have been made to minimize this bias. Lai et al. ${ }^{[55]}$ excluded patients with self-reported cirrhosis at baseline, and the inverse association found in the whole cohort did not change even after the removal of the first two and five years of follow-up, and it was similar in cases occurring during the first or last 10 years. Moreover, the HCC risk reduction demonstrated in coffee consumers with CLD was similar to that found in studies using subjects with no liver disease as controls ${ }^{[52]}$. When coffee consumption was evaluated before and after the first diagnosis of liver disease, a protective effect of coffee was demonstrated in both cases ${ }^{[68]}$. In addition, several studies reported an inverse relation between coffee consumption and liver cancer risk among patients with serological evidence of hepatitis ${ }^{[22,23,25,59,61]}$.

Many studies collected data at a single time point, failing to capture the long-term coffee consumption and not considering that coffee intake may have varied over time ${ }^{[24-27,54-56,58,59]}$. Other limitations derive from the lack of standardization among different studies. Coffee is a complex mixture of many compounds, and different types of coffee may vary in their chemical composition ${ }^{[1]}$. Moreover, all studies failed to define coffee cup size ${ }^{[46]}$, which leads to ambiguity regarding the exact amount of coffee intake necessary to achieve health effects. In addition, the duration of coffee consumption required to decrease the risk of HCC is unknown.

Even after considering all the limitations of observational studies, it is unlikely that such a consistently and repeatedly reported inverse association between coffee consumption and liver cancer risk is explained by chance. Publication bias (the selective publication of studies with positive results) could be another concern, but it is unlikely to account for such a strong relation. Therefore, it can be concluded that the inverse relation between coffee and liver cancer is real.

While the inverse association between coffee consumption and liver cancer risk could be considered as a fact, the protective effect on the development of other tumors has not yet been fully demonstrated ${ }^{[79]}$. A large prospective cohort study and a recent review of metanalyses did not found a risk reduction in coffee consumers for cancers other than $\mathrm{HCC}^{[48,79]}$. Primary liver cancer develops almost invariably on a background of chronic liver disease. Coffee exerts its "hepatoprotective" health benefits in the whole spectrum of liver diseases: it reduces transaminases and g-glutamiltransferase (GGT) levels, slows the progression of chronic liver disease and fibrosis, and decreases the risk of cirrhosis ${ }^{[46]}$. In HCC, coffee consumption prevents the development and progression of pre-neoplastic conditions (i.e., chronic liver diseases), which should be considered when interpreting the strong and peculiar inverse association 
between the risk of this tumor and coffee compared to other cancers.

\section{PROPOSED MECHANISMS FOR COFFEE PROTECTIVE EFFECTS}

The biological mechanism behind coffee consumption and HCC risk reduction is still unclear. As mentioned above, coffee is a complex beverage composed of thousands of physiologically active chemical compounds $s^{[37,38]}$. Firstly, caffeine is proven to be able to prevent hepatic stellate cell adhesion and activation $^{[80]}$, exerting its protective effects by beta oxidative stimulation of lipolysis, lipogenesis, and oxidative stress suppression ${ }^{[81,82]}$. It has been demonstrated to be protective against the progression liver fibrosis: in a rat model of alcohol-induced liver fibrosis, it inhibited the cAMP/protein kinase A/cAMP response element-binding protein signal pathway, decreased malondialdehyde (MDA) levels, and increased glutathione peroxidase (GPx) activity in the liver ${ }^{[83,84]}$.

Moreover, caffeine emerged in several studies as an important substance with chemopreventive properties, including in liver carcinogenesis ${ }^{[85,86]}$. In vitro studies demonstrated that caffeine causes cell cycle arrest and inhibits cell proliferation, by blocking the PI3K/Akt pathway ${ }^{[80,87]}$. Two studies investigated the effect of caffeine in liver carcinogenesis in vivo, demonstrating a reduced incidence and number of HCC lesions in caffeine-treated rats ${ }^{[32]}$.

Other coffee components have been investigated for their role as chemopreventive substances. Chlorogenic acid was able to reduce the number of hyperplastic liver cell foci in methylazoxymethanol-treated hamsters ${ }^{[88]}$. Subsequently, Yan et al. ${ }^{[89]}$ demonstrated that chlorogenic acid reduced mitogen-activated protein kinase activation and phosphorylation of ERK1/2 in vitro; moreover, its intraperitoneal administration reduced liver tumor volume and weight in HepG2 xenografts in vivo. Chlorogenic acid, and its metabolite caffeic acid, showed potent antioxidant activity in vitro and in animal models, as suggested by the reduced levels of hepatic lipid peroxidation and glutathione in a rat model with ischemia/reperfusion injury ${ }^{[00-92]}$. Diterpenes (cafestol and kahweol) may have an antioxidant action by increasing the levels of glutathione-S-transferases $(\mathrm{GSH})^{[33,93-95]}$, a glutathione catalyzing enzyme inversely associated with liver carcinogenesis $^{[96]}$. An increased expression of enzymes involved in the synthesis of endogenous antioxidants has been demonstrated in animals treated with coffee diterpenes ${ }^{[97]}$. Cafestol and kahweol are able to promote the transcription of g-glutamyl cysteine synthetase and heme oxygenase-1, two proteins involved in cellular antioxidant respons ${ }^{[98]}$. Their antioxidant properties have also been demonstrated in mice with carbon tetrachloride-induced liver damage: cafestol and kahweol pretreatment reduced glutathione content and lipid peroxidation in the liver, and the two molecules exerted superoxide scavenging activities ${ }^{[99]}$. Cafestol and kahweol administration was associated with a 50\% decrease in DNA adduct formation, potentially reducing cancer-driver mutations ${ }^{[94]}$. Melanoidins, brown-colored compounds in coffee, exert antioxidant activity by reducing tumor necrosis factor (TNF)-alpha, tissue transglutaminase, and transforming growth factor (TGF)-beta in the liver ${ }^{[100,101]}$.

It is likely that no one of these constituents alone could explain the preventive effect of coffee on the risk of liver cancer observed in epidemiological studies, but the benefit of coffee consumption derives from the beverage as a whole. Among the studies conducted to evaluate the effect of whole coffee consumption in liver carcinogenesis, only Hasegawa et al. ${ }^{[102]}$ found no differences in dimethylnitrosamine-induced tumor frequency and location in coffee-treated rats, while all other studies demonstrated a reduction in tumor number and size ${ }^{[103-107]}$. In the antineoplastic properties of coffee, the induction of the apoptotic process seems to be of central importance $e^{[103,105]}$. 
Coffee is one of the major sources of antioxidants in the diet ${ }^{[108]}$. It is a strong inducer of nuclear factor erythroid-related factor $(\mathrm{NrF} 2)$, a transcription factor that controls antioxidant defense, as well as glutathione synthetases and reductase ${ }^{[109]}$. Some data demonstrate the upregulation of antioxidant enzymes, in particular superoxide dismutase, and the reduction of DNA-damage caused by reactive oxygen radical as a consequence of coffee administration ${ }^{[110]}$. Among the beneficial effects of coffee intake, the protection from oxidative stress, which emerged as a key factor in the progression of liver fibrosis, appears to be of particular importance. As demonstrated by data published by our research group ${ }^{[11-113]}$, the status of oxidative stress is a central inducer of liver damage and progression into hepatic fibrosis in various chronic liver disorders. In liver injuries caused by alcohol consumption, $\mathrm{NASH}$, and chronic viral hepatitis, the overproduction of reactive oxygen species (ROS) by damaged hepatocytes causes the depletion of endogenous antioxidants; the consequent activation of Kupffer cells and hepatic stellate cells leads to the induction of fibrogenic cytokines, such as TGF-beta, platelet-derived growth factor (PDGF)-beta, and TNF-alpha, and to the accumulation of extracellular matrix ${ }^{[114]}$.

Some studies investigating the protective effect of coffee consumption on oxidative stress have been conducted in humans, with erratic results. Shaposhnikov et al. ${ }^{[115]}$ conducted a placebo-controlled trial in 160 healthy volunteers administering three or five cups of coffee per day for eight weeks ( $v s$. water), finding comparable levels of liver enzymes (except a small increase in GGT in coffee drinkers) and biomarkers for oxidative stress or inflammation. A few years ago, we also conducted a randomized study with a cross-over design (four coffee cups/day consumption or abstinence for one month, with cross-over at the end of this period) to investigate antioxidant properties of coffee in patients with chronic $\mathrm{HCV}$ infection ${ }^{[16]}$. Chronic hepatitis C is characterized by increased ROS production ${ }^{[11,117]}$, with antioxidants depletion and accumulation of oxidative DNA damage, which is a significant and independent risk factor for progression to $\mathrm{HCC}^{[118-121]}$. This may be due to the formation of 8-hydroxydeoxyguanosine from guanine residues: this is an adduct marker of oxidative DNA damage that accumulates, causing mispairing and DNA mutation, with ROS damaging in particular telomeric segments, in which guanine is more represented ${ }^{[122]}$. The consequent telomere shortening leads to chromosome instability in the early phases of carcinogenesis, while late reactivation of telomerase activity causes telomere elongation and cell immortalization ${ }^{[123]}$. In our study, the consumption of four cups/day of coffee was associated with a lower level of AST and GGT and a two-fold decreased level of 8-hydroxydeoxyguanosine. Moreover, in patients drinking at least four cups of coffee per day, we demonstrated a reduction in collagen synthesis and oxidative DNA damage and an increase in telomere length and circulating apoptotic markers ${ }^{[116]}$ [Figure 1]. The reasons coffee has beneficial effects only in the prevention of hepatocarcinogenesis, and not other types of cancer, are hardly explainable. Oxidative stress damage, with depletion in antioxidants and accumulation of DNA damage ${ }^{[118]}$, is one of the key factors promoting liver diseases progression and evolution to $\mathrm{HCC}^{[116,119,120,124,125]}$. Moreover, oxidative DNA damage is an independent risk factor for $\mathrm{HCC}^{[121]}$. Considering the pivotal role of oxidative stress damage in liver carcinogenesis might explain why coffee, an important source of antioxidants, is particularly effective in preventing this tumor.

In addition to antioxidant properties, coffee also has other beneficial effects on liver health, in particular anti-inflammatory activities. In humans, coffee intake has been inversely associated with inflammatory marker levels, such as E-selectin and c-reactive protein ${ }^{[126]}$, this being probably due to coffee inhibiting expression of genes involved in inflammatory process, such as TNF-alpha, interleukin (IL)-6, and interferon (IFN)-gamma ${ }^{[107]}$.

In a study conducted in a dimethylnitrosamine-induced liver fibrosis model, coffee administration significantly reduced necrosis, inflammation, and fibrotic septa, at histopathological examination. 

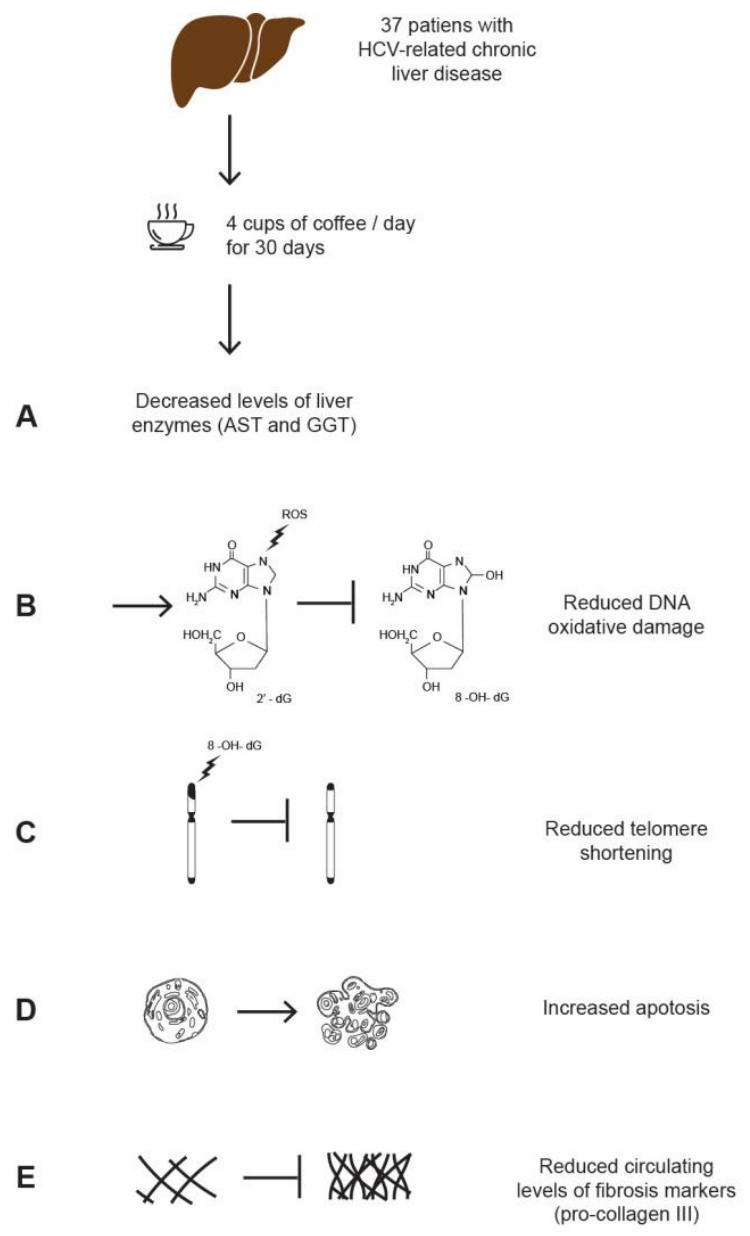

Figure 1. Representative scheme of the randomized trial by Cardin et al. ${ }^{[16]}$, investigating the protective effects of coffee in 40 patients with HCV-related chronic liver disease. Patients were divided in two groups, the first consuming four cups of coffee/day for 30 days and the second abstaining from coffee intake. At the end of this period, there was a cross-over between the two groups. After the withdraw of three patients, the analyses were performed in the remaining 37. Compared to no coffee intake, consuming 4 cups of coffee/day for one month resulted in: a decrease of AST and GGT (A); a reduction in DNA oxidative damage, as demonstrated by the decreased levels of circulating 8-hydroxydeoxyguanosine (8-OH-dG) (B); a reduced telomere shortening, with DNA stabilization (C); an increase in apoptosis, with an increased level of the apoptotic marker CK-18 (D); and reduced collagen deposition, as demonstrated by reduced circulating pro-collagen III (E).

Moreover, accumulation of hydroxyproline and production of malondialdehyde (an oxidative index) were inhibited, and gene expressions of inducible nitric oxide synthase (responsible for ROS production), TGFbeta, TNF-alpha, IL-1, and PDGF-beta, as fibrogenic cytokines, were reduced. In addition, coffee avoided in part the depletion of glutathione, superoxide dismutase, and catalase in liver tissue ${ }^{[127]}$.

The role of microRNAs in modulating the chemopreventive properties of coffee is emerging. MicroRNAs are small non-coding single-stranded RNA molecules, extensively involved in the regulation of gene expression. They may act as onco-suppressors or oncogenes, acting on major tumor-related genes involved in human carcinogenesis ${ }^{[128]}$. In a recent study on a mice model ${ }^{[129]}$, the combination of three coffee compounds (caffeine, trigonelline, and chlorogenic acid) attenuated preneoplastic lesion development, decreased proliferation in preneoplastic foci, increased apoptosis, induced antioxidant response, and reduced fibrosis and oxidative stress. All these beneficial effects were obtained by all three substances by 
upregulating miR-144-3p, miR-376a-3p, and miR-15b-5p. As the authors reported, these results allow speculating that the beneficial effect of coffee on liver health may be partially due to the modulation of tumor-suppressor and antifibrotic microRNAs ${ }^{[129]}$. In light of these results, we are planning to evaluate the role of some microRNAs, in particular miR-21, in oxidative stress and inflammation, as well as their possible modulation by coffee consumption in humans.

\section{CONCLUSION}

Coffee is beneficial for liver health, and several epidemiological studies demonstrate a dose-response inverse association between coffee intake and HCC risk. However, translating these observations into clinical practice and specifically into the prevention of liver cancer by giving indications to increasing coffee consumption is still far away. Randomized controlled trials should be performed in order to provide evidence of causation, eliminate the confounding and bias inherent to observational studies, and define the standard doses necessary to prevent HCC development. Additional in vitro and in vivo experiments are necessary to elucidate the biological mechanism behind these chemopreventive properties of coffee.

On the basis of what is currently known, we can conclude that coffee intake should not be considered a "bad habit". There is no sufficient evidence to prescribe coffee in patients at risk of developing HCC, but moderate daily consumption of coffee should be encouraged in patients who are already doing so. Coffee consumption has proved to be beneficial in reducing the risk of NAFLD ${ }^{[130,131]}$ and the development of hepatic fibrosis ${ }^{[1,44]}$, and it may be also useful in reducing HCC risk in patients with metabolic-associated liver disease. Additional studies should be performed to evaluate the effect of coffee on HCC risk reduction in patients with NAFLD. However, considering the recently mutated epidemiological scenario, with the decreased incidence of HCC in chronically infected HCV patients and the increase of liver tumor related to metabolic diseases ${ }^{[132,133]}$, recommending a moderate coffee intake in these patients could be reasonable.

\section{DECLARATIONS}

\section{Authors' contributions}

Conceptualized and designed the review: Farinati F

Wrote, reviewed and edited the manuscript: Pelizzaro F, Cardin R

Reviewed the manuscript for intellectual content: Sartori A, Imondi A, Penzo B, Farinati F

Approved the final version for submission: Pelizzaro F, Cardin R, Sartori A, Imondi A, Penzo B, Farinati F

\section{Availability of data and materials}

Not applicable.

\section{Financial support and sponsorship}

None.

\section{Conflicts of interest}

All authors declared that there are no conflicts of interest.

\section{Ethical approval and consent to participate}

Not applicable.

\section{Consent for publication}

Not applicable. 


\section{Copyright}

(C) The Author(s) 2021.

\section{REFERENCES}

1. Yesil A, Yilmaz Y. Review article: coffee consumption, the metabolic syndrome and non-alcoholic fatty liver disease. Aliment Pharmacol Ther 2013;38:1038-44. DOI PubMed

2. Huxley R, Lee CM, Barzi F, et al. Coffee, decaffeinated coffee, and tea consumption in relation to incident type 2 diabetes mellitus: a systematic review with meta-analysis. Arch Intern Med 2009;169:2053-63. DOI PubMed

3. Lopez-Garcia E, Rodriguez-Artalejo F, Rexrode KM, Logroscino G, Hu FB, van Dam RM. Coffee consumption and risk of stroke in women. Circulation 2009;119:1116-23. DOI PubMed PMC

4. Larsson SC, Männistö S, Virtanen MJ, Kontto J, Albanes D, Virtamo J. Coffee and tea consumption and risk of stroke subtypes in male smokers. Stroke 2008;39:1681-7. DOI PubMed

5. Larsson SC, Virtamo J, Wolk A. Coffee consumption and risk of stroke in women. Stroke 2011;42:908-12. DOI PubMed

6. Ruhl CE, Everhart JE. Association of coffee consumption with gallbladder disease. Am J Epidemiol 2000;152:1034-8. DOI PubMed

7. Ascherio A, Zhang SM, Hernán MA, et al. Prospective study of caffeine consumption and risk of Parkinson's disease in men and women. Ann Neurol 2001;50:56-63. DOI PubMed

8. Wu JN, Ho SC, Zhou C, et al. Coffee consumption and risk of coronary heart diseases: a meta-analysis of 21 prospective cohort studies. Int J Cardiol 2009;137:216-25. DOI PubMed

9. Freedman ND, Park Y, Abnet CC, Hollenbeck AR, Sinha R. Association of coffee drinking with total and cause-specific mortality. $N$ Engl J Med 2012;366:1891-904. DOI PubMed PMC

10. Klatsky AL, Morton C, Udaltsova N, Friedman GD. Coffee, cirrhosis, and transaminase enzymes. Arch Intern Med 2006;166:1190-5. DOI PubMed

11. Nakanishi N, Nakamura K, Nakajima K, Suzuki K, Tatara K. Coffee consumption and decreased serum $\gamma$-glutamyltransferase: a study of middle-aged Japanese men. Eur J Epidemiol 2000;16:419-23. DOI PubMed

12. Ruhl CE, Everhart JE. Coffee and caffeine consumption reduce the risk of elevated serum alanine aminotransferase activity in the United States. Gastroenterology 2005;128:24-32. DOI PubMed

13. Modi AA, Feld JJ, Park Y, et al. Increased caffeine consumption is associated with reduced hepatic fibrosis. Hepatology 2010;51:201-9. DOI PubMed PMC

14. Ruhl CE, Everhart JE. Coffee and tea consumption are associated with a lower incidence of chronic liver disease in the United States. Gastroenterology 2005;129:1928-36. DOI PubMed

15. Freedman ND, Curto TM, Lindsay KL, Wright EC, Sinha R, Everhart JE; HALT-C TRIAL GROUP. Coffee consumption is associated with response to peginterferon and ribavirin therapy in patients with chronic hepatitis C. Gastroenterology 2011;140:19619. DOI PubMed PMC

16. Corrao G, Zambon A, Bagnardi V, D'amicis A, Klatsky A. Coffee, Caffeine, and the Risk of Liver Cirrhosis. Ann Epidemiol 2001;11:458-65. DOI PubMed

17. Gallus S, Tavani A, Negri E, La Vecchia C. Does Coffee Protect Against Liver Cirrhosis? Ann Epidemiol 2002;12:202-5. DOI PubMed

18. Birerdinc A, Stepanova M, Pawloski L, Younossi ZM. Caffeine is protective in patients with non-alcoholic fatty liver disease. Aliment Pharmacol Ther 2012;35:76-82. DOI PubMed

19. Molloy JW, Calcagno CJ, Williams CD, Jones FJ, Torres DM, Harrison SA. Association of coffee and caffeine consumption with fatty liver disease, nonalcoholic steatohepatitis, and degree of hepatic fibrosis. Hepatology 2012;55:429-36. DOI PubMed

20. Klatsky AL, Armstrong MA. Alcohol, smoking, coffee, and cirrhosis. Am J Epidemiol 1992;136:1248-57. DOI PubMed

21. Tverdal A, Skurtveit S. Coffee Intake and Mortality from Liver Cirrhosis. Annals of Epidemiology 2003;13:419-23. DOI PubMed

22. Gallus S, Bertuzzi M, Tavani A, et al. Does coffee protect against hepatocellular carcinoma? Br J Cancer 2002;87:956-9. DOI PubMed PMC

23. Gelatti U, Covolo L, Franceschini M, et al; Brescia HCC Study Group. Coffee consumption reduces the risk of hepatocellular carcinoma independently of its aetiology: a case-control study. J Hepatol 2005;42:528-34. DOI PubMed

24. Shimazu T, Tsubono Y, Kuriyama S, et al. Coffee consumption and the risk of primary liver cancer: pooled analysis of two prospective studies in Japan. Int J Cancer 2005;116:150-4. DOI PubMed

25. Inoue M, Yoshimi I, Sobue T, Tsugane S; JPHC Study Group. Influence of coffee drinking on subsequent risk of hepatocellular carcinoma: a prospective study in Japan. J Natl Cancer Inst 2005;97:293-300. DOI PubMed

26. Hu G, Tuomilehto J, Pukkala E, et al. Joint effects of coffee consumption and serum gamma-glutamyltransferase on the risk of liver cancer. Hepatology 2008;48:129-36. DOI PubMed

27. Petrick JL, Freedman ND, Graubard BI, et al. Coffee consumption and risk of hepatocellular carcinoma and intrahepatic cholangiocarcinoma by sex: the liver cancer pooling project. Cancer Epidemiol Biomarkers Prev 2015;24:1398-406. DOI PubMed $\mathrm{PMC}$

28. Larsson SC, Wolk A. Coffee consumption and risk of liver cancer: a meta-analysis. Gastroenterology 2007;132:1740-5. DOI PubMed

29. Bravi F, Bosetti C, Tavani A, et al. Coffee drinking and hepatocellular carcinoma risk: a meta-analysis. Hepatology 2007;46:430-5. DOI PubMed 
30. Bravi F, Bosetti C, Tavani A, Gallus S, La Vecchia C. Coffee reduces risk for hepatocellular carcinoma: an updated meta-analysis. Clin Gastroenterol Hepatol 2013;11:1413-21.e1. DOI PubMed

31. Bravi F, Tavani A, Bosetti C, Boffetta P, La Vecchia C. Coffee and the risk of hepatocellular carcinoma and chronic liver disease: a systematic review and meta-analysis of prospective studies. Eur J Cancer Prev 2017;26:368-77. DOI PubMed

32. Hosaka S, Kawa S, Aoki Y, et al. Hepatocarcinogenesis inhibition by caffeine in ACI rats treated with 2-acetylaminofluorene. Food Chem Toxicol 2001;39:557-61. DOI PubMed

33. Huber WW, Prustomersky S, Delbanco E, et al. Enhancement of the chemoprotective enzymes glucuronosyl transferase and glutathione transferase in specific organs of the rat by the coffee components kahweol and cafestol. Arch Toxicol 2002;76:209-17. DOI PubMed

34. Bray F, Ferlay J, Soerjomataram I, Siegel RL, Torre LA, Jemal A. Global cancer statistics 2018: GLOBOCAN estimates of incidence and mortality worldwide for 36 cancers in 185 countries. CA Cancer J Clin 2018;68:394-424. DOI PubMed

35. Forner A, Reig M, Bruix J. Hepatocellular carcinoma. Lancet 2018;391:1301-14. DOI PubMed

36. Ambade A, Mandrekar P. Oxidative stress and inflammation: essential partners in alcoholic liver disease. Int J Hepatol 2012;2012:853175. DOI PubMed PMC

37. Butt MS, Sultan MT. Coffee and its consumption: benefits and risks. Crit Rev Food Sci Nutr 2011;51:363-73. DOI PubMed

38. Dórea JG, da Costa TH. Is coffee a functional food? Br J Nutr 2005;93:773-82. DOI PubMed

39. Ratnayake W, Hollywood R, O'grady E, Stavric B. Lipid content and composition of coffee brews prepared by different methods. Food Chem Toxicol 1993;31:263-9. DOI PubMed

40. Dranoff JA. Coffee Consumption and Prevention of Cirrhosis: In Support of the Caffeine Hypothesis. Gene Expr 2018;18:1-3. DOI PubMed PMC

41. Glade MJ. Caffeine-Not just a stimulant. Nutrition 2010;26:932-8. DOI PubMed

42. Yashin A, Yashin Y, Wang JY, Nemzer B. Antioxidant and antiradical activity of coffee. Antioxidants ;2:230-45. DOI PubMed PMC

43. Anese M, Nicoli MC. Antioxidant properties of ready-to-drink coffee brews. J Agric Food Chem 2003;51:942-6. DOI PubMed

44. Anty R, Marjoux S, Iannelli A, et al. Regular coffee but not espresso drinking is protective against fibrosis in a cohort mainly composed of morbidly obese European women with NAFLD undergoing bariatric surgery. J Hepatol 2012;57:1090-6. DOI PubMed

45. Urgert R, Schulz AG, Katan MB. Effects of cafestol and kahweol from coffee grounds on serum lipids and serum liver enzymes in humans. Am J Clin Nutr 1995;61:149-54. DOI PubMed

46. Saab S, Mallam D, Cox GA 2nd, Tong MJ. Impact of coffee on liver diseases: a systematic review. Liver Int 2014;34:495-504. DOI PubMed

47. Duarte GS, Farah A. Effect of simultaneous consumption of milk and coffee on chlorogenic acids' bioavailability in humans. $J$ Agric Food Chem 2011;59:7925-31. DOI PubMed

48. Tran KT, Coleman HG, McMenamin ÚC, Cardwell CR. Coffee consumption by type and risk of digestive cancer: a large prospective cohort study. Br J Cancer 2019;120:1059-66. DOI PubMed PMC

49. La Vecchia C, Ferraroni M, Negri E, D’Avanzo B, Decarli A, et al. Coffee consumption and digestive tract cancers. Cancer Res 1989;49:1049-51. PubMed

50. Kuper H, Tzonou A, Kaklamani E, et al. Tobacco smoking, alcohol consumption and their interaction in the causation of hepatocellular carcinoma. Int $J$ Cancer 2000;85:498-502. PubMed

51. Montella M, Polesel J, La Vecchia C, et al. Coffee and tea consumption and risk of hepatocellular carcinoma in Italy. Int J Cancer 2007;120:1555-9. DOI PubMed

52. Tanaka K, Hara M, Sakamoto T, et al. Inverse association between coffee drinking and the risk of hepatocellular carcinoma: a casecontrol study in Japan. Cancer Sci 2007;98:214-8. DOI PubMed

53. Johnson S, Koh WP, Wang R, Govindarajan S, Yu MC, Yuan JM. Coffee consumption and reduced risk of hepatocellular carcinoma: findings from the Singapore Chinese Health Study. Cancer Causes Control 2011;22:503-10. DOI PubMed PMC

54. Setiawan VW, Wilkens LR, Lu SC, Hernandez BY, Le Marchand L, Henderson BE. Association of coffee intake with reduced incidence of liver cancer and death from chronic liver disease in the US multiethnic cohort. Gastroenterology 2015;148:118-25; quiz e15. DOI PubMed PMC

55. Lai GY, Weinstein SJ, Albanes D, et al. The association of coffee intake with liver cancer incidence and chronic liver disease mortality in male smokers. Br J Cancer 2013;109:1344-51. DOI PubMed PMC

56. Bamia C, Lagiou P, Jenab M, et al. Coffee, tea and decaffeinated coffee in relation to hepatocellular carcinoma in a European population: multicentre, prospective cohort study. Int J Cancer 2015;136:1899-908. DOI PubMed PMC

57. Aleksandrova K, Bamia C, Drogan D, et al. The association of coffee intake with liver cancer risk is mediated by biomarkers of inflammation and hepatocellular injury: data from the European Prospective Investigation into Cancer and Nutrition. Am J Clin Nutr 2015;102:1498-508. DOI PubMed PMC

58. Kurozawa Y, Ogimoto I, Shibata A, et al; JACC Study Group. Coffee and risk of death from hepatocellular carcinoma in a large cohort study in Japan. Br J Cancer 2005;93:607-10. DOI PubMed PMC

59. Wakai K, Kurozawa Y, Shibata A, et al; JACC Study Group. Liver cancer risk, coffee, and hepatitis C virus infection: a nested casecontrol study in Japan. Br J Cancer 2007;97:426-8. DOI PubMed PMC

60. Ohfuji S, Fukushima W, Tanaka T, et al. Coffee consumption and reduced risk of hepatocellular carcinoma among patients with chronic type C liver disease: A case-control study. Hepatol Res 2006;36:201-8. DOI PubMed

61. Jang ES, Jeong SH, Lee SH, et al. The effect of coffee consumption on the development of hepatocellular carcinoma in hepatitis B 
virus endemic area. Liver Int 2013;33:1092-9. DOI PubMed

62. Leung WW, Ho SC, Chan HL, Wong V, Yeo W, Mok TS. Moderate coffee consumption reduces the risk of hepatocellular carcinoma in hepatitis B chronic carriers: a case-control study. J Epidemiol Community Health 2011;65:556-8. DOI PubMed

63. Bravi F, Bosetti C, Tavani A, La Vecchia C. Coffee drinking and hepatocellular carcinoma: an update. Hepatology 2009;50:1317-8. DOI PubMed

64. Sang LX, Chang B, Li XH, Jiang M. Consumption of coffee associated with reduced risk of liver cancer: a meta-analysis. $B M C$ Gastroenterol 2013;13:34. DOI PubMed PMC

65. Bai K, Cai Q, Jiang Y, Lv L. Coffee consumption and risk of hepatocellular carcinoma: a meta-analysis of eleven epidemiological studies. Onco Targets Ther 2016;9:4369-75. DOI PubMed PMC

66. Yu C, Cao Q, Chen P, et al. An updated dose-response meta-analysis of coffee consumption and liver cancer risk. Sci Rep 2016;6:37488. DOI PubMed PMC

67. Kennedy OJ, Roderick P, Buchanan R, Fallowfield JA, Hayes PC, Parkes J. Coffee, including caffeinated and decaffeinated coffee, and the risk of hepatocellular carcinoma: a systematic review and dose-response meta-analysis. BMJ Open 2017;7:e13739. DOI PubMed PMC

68. Bhurwal A, Rattan P, Yoshitake S, et al. Inverse association of coffee with liver cancer development: an updated systematic review and meta-analysis. J Gastrointestin Liver Dis 2020;29:421-8. DOI PubMed

69. Inoue M, Kurahashi N, Iwasaki M, et al; Japan Public Health Center-Based Prospective Study Group. Effect of coffee and green tea consumption on the risk of liver cancer: cohort analysis by hepatitis virus infection status. Cancer Epidemiol Biomarkers Prev 2009; 18:1746-53. DOI PubMed

70. Ouyang X, Cirillo P, Sautin Y, et al. Fructose consumption as a risk factor for non-alcoholic fatty liver disease. J Hepatol 2008;48:993-9. DOI PubMed PMC

71. Desmond PV, Patwardhan RV, Johnson RF, Schenker S. Impaired elimination of caffeine in cirrhosis. Dig Dis Sci 1980;25:193-7. DOI PubMed

72. Vecchia C. Cancer and liver cancer prevention: is it a fact or just a potential? Hepatology 2008;48:7-9. DOI PubMed

73. Holstege A, Staiger M, Haag K, Gerok W. Correlation of caffeine elimination and Child's classification in liver cirrhosis. Klin Wochenschr 1989;67:6-15. DOI PubMed

74. Jost G, Wahlländer A, von Mandach U, Preisig R. Overnight salivary caffeine clearance: a liver function test suitable for routine use. Hepatology 1987;7:338-44. DOI PubMed

75. McDonagh JE, Nathan VV, Bonavia IC, Moyle GR, Tanner AR. Caffeine clearance by enzyme multiplied immunoassay technique: a simple, inexpensive, and useful indicator of liver function. Gut 1991;32:681-4. DOI PubMed PMC

76. Lewis FW, Rector WG. Caffeine clearance in cirrhosis. The value of simplified determinations of liver metabolic capacity. J Hepatol 1992;14:157-62. DOI PubMed

77. Tarantino G, Conca P, Capone D, Gentile A, Polichetti G, Basile V. Reliability of total overnight salivary caffeine assessment (TOSCA) for liver function evaluation in compensated cirrhotic patients. Eur J Clin Pharmacol 2006;62:605-12. DOI PubMed

78. Farinati F, Dalri' L, Rossaro L, et al. Serum and salivary caffeine clearance in cirrhosis. Any role in selection for surgery and timing for transplantation? J Hepatol 1993;18:135-6. DOI PubMed

79. Zhao LG, Li ZY, Feng GS, et al. Coffee drinking and cancer risk: an umbrella review of meta-analyses of observational studies. BMC Cancer 2020;20:101. DOI PubMed PMC

80. Shim SG, Jun DW, Kim EK, et al. Caffeine attenuates liver fibrosis via defective adhesion of hepatic stellate cells in cirrhotic model. J Gastroenterol Hepatol 2013;28:1877-84. DOI PubMed

81. Sinha RA, Farah BL, Singh BK, et al. Caffeine stimulates hepatic lipid metabolism by the autophagy-lysosomal pathway in mice. Hepatology 2014;59:1366-80. DOI PubMed

82. Lv X, Chen Z, Li J, et al. Caffeine protects against alcoholic liver injury by attenuating inflammatory response and oxidative stress. Inflamm Res 2010;59:635-45. DOI PubMed

83. Wang Q, Dai X, Yang W, et al. Caffeine protects against alcohol-induced liver fibrosis by dampening the cAMP/PKA/CREB pathway in rat hepatic stellate cells. Int Immunopharmacol 2015;25:340-52. DOI PubMed

84. Arauz J, Zarco N, Segovia J, Shibayama M, Tsutsumi V, Muriel P. Caffeine prevents experimental liver fibrosis by blocking the expression of TGF- $\beta$. Eur J Gastroenterol Hepatol 2014;26:164-73. DOI PubMed

85. Okano J. Preventive effect of caffeine and curcumin on hepato-carcinogenesis in diethylnitrosamine-induced rats. Int J Oncol 2012. DOI PubMed

86. Tverdal A, Hjellvik V, Selmer R. Coffee intake and oral-oesophageal cancer: follow-up of 389,624 Norwegian men and women 4045 years. Br J Cancer 2011;105:157-61. DOI PubMed PMC

87. Edling CE, Selvaggi F, Ghonaim R, Maffucci T, Falasca M. Caffeine and the analog CGS 15943 inhibit cancer cell growth by targeting the phosphoinositide 3-kinase/Akt pathway. Cancer Biol Ther 2014;15:524-32. DOI PubMed PMC

88. Mori H, Tanaka T, Shima H, Kuniyasu T, Takahashi M. Inhibitory effect of chlorogenic acid on methylazoxymethanol acetateinduced carcinogenesis in large intestine and liver of hamsters. Cancer Letters 1986;30:49-54. DOI PubMed

89. Yan Y, Liu N, Hou N, Dong L, Li J. Chlorogenic acid inhibits hepatocellular carcinoma in vitro and in vivo. J Nutr Biochem 2017;46:68-73. DOI PubMed

90. Sato Y, Itagaki S, Kurokawa T, et al. In vitro and in vivo antioxidant properties of chlorogenic acid and caffeic acid. Int J Pharm 2011;403:136-8. DOI PubMed

91. Yun N, Kang JW, Lee SM. Protective effects of chlorogenic acid against ischemia/reperfusion injury in rat liver: molecular evidence 
of its antioxidant and anti-inflammatory properties. J Nutr Biochem 2012;23:1249-55. DOI PubMed

92. Torres DM, Harrison SA. Is it time to write a prescription for coffee? Gastroenterology 2013;144:670-2. DOI PubMed

93. Schilter B, Perrin I, Cavin C, Huggett AC. Placental glutathione S-transferase (GST-P) induction as a potential mechanism for the anti-carcinogenic effect of the coffee-specific components cafestol and kahweol. Carcinogenesis 1996;17:2377-84. DOI PubMed

94. Cavin C, Holzhäuser D, Constable A, Huggett AC, Schilter B. The coffee-specific diterpenes cafestol and kahweol protect against aflatoxin B1-induced genotoxicity through a dual mechanism. Carcinogenesis 1998;19:1369-75. DOI PubMed

95. Huber WW, Rossmanith W, Grusch M, et al. Effects of coffee and its chemopreventive components kahweol and cafestol on cytochrome P450 and sulfotransferase in rat liver. Food Chem Toxicol 2008;46:1230-8. DOI PubMed

96. Sparnins V, Venegas P, Wattenberg L. Glutathione S-transferase activity: enhancement by compounds inhibiting chemical carcinogenesis and by dietary constituents. J Natl Cancer Inst 1982;68:493-6. PubMed

97. Higgins LG, Cavin C, Itoh K, Yamamoto M, Hayes JD. Induction of cancer chemopreventive enzymes by coffee is mediated by transcription factor Nrf2. Evidence that the coffee-specific diterpenes cafestol and kahweol confer protection against acrolein. Toxicol Appl Pharmacol 2008;226:328-37. DOI PubMed

98. Cavin C, Holzhaeuser D, Scharf G, Constable A, Huber W, Schilter B. Cafestol and kahweol, two coffee specific diterpenes with anticarcinogenic activity. Food Chem Toxicol 2002;40:1155-63. DOI PubMed

99. Lee KJ, Choi JH, Jeong HG. Hepatoprotective and antioxidant effects of the coffee diterpenes kahweol and cafestol on carbon tetrachloride-induced liver damage in mice. Food Chem Toxicol 2007;45:2118-25. DOI PubMed

100. Vitaglione P, Morisco F, Mazzone G, et al. Coffee reduces liver damage in a rat model of steatohepatitis: the underlying mechanisms and the role of polyphenols and melanoidins. Hepatology 2010;52:1652-61. DOI PubMed

101. Chen S, Teoh NC, Chitturi S, Farrell GC. Coffee and non-alcoholic fatty liver disease: brewing evidence for hepatoprotection? $J$ Gastroenterol Hepatol 2014;29:435-41. DOI PubMed

102. Hasegawa R, Ogiso T, Imaida K, Shirai T, Ito N. Analysis of the potential carcinogenicity of coffee and its related compounds in a medium-term liver bioassay of rats. Food Chem Toxicol 1995;33:15-20. DOI PubMed

103. Miura Y, Ono K, Okauchi R, Yagasaki K. Inhibitory effect of coffee on hepatoma proliferation and invasion in culture and on tumor growth, metastasis and abnormal lipoprotein profiles in hepatoma-bearing rats. J Nutr Sci Vitaminol (Tokyo) 2004;50:38-44. DOI PubMed

104. Silva-Oliveira EM, Fernandes PA, Moraes-Santos T. Effect of coffee on chemical hepatocarcinogenesis in rats. Nutr Cancer 2010;62:336-42. DOI PubMed

105. Furtado KS, Polletini J, Dias MC, Rodrigues MA, Barbisan LF. Prevention of rat liver fibrosis and carcinogenesis by coffee and caffeine. Food Chem Toxicol 2014;64:20-6. DOI PubMed

106. Ferk F, Huber WW, Grasl-Kraupp B, et al. Protective effects of coffee against induction of DNA damage and pre-neoplastic foci by aflatoxin B 1 . Mol Nutr Food Res 2014;58:229-38. DOI PubMed

107. Katayama M, Donai K, Sakakibara H, et al. Coffee consumption delays the hepatitis and suppresses the inflammation related gene expression in the Long-Evans Cinnamon rat. Clin Nutr 2014;33:302-10. DOI PubMed

108. Svilaas A, Sakhi AK, Andersen LF, et al. Intakes of antioxidants in coffee, wine, and vegetables are correlated with plasma carotenoids in humans. J Nutr 2004;134:562-7. DOI PubMed

109. Balstad TR, Carlsen H, Myhrstad MC, et al. Coffee, broccoli and spices are strong inducers of electrophile response elementdependent transcription in vitro and in vivo - studies in electrophile response element transgenic mice. Mol Nutr Food Res 2011;55:185-97. DOI PubMed

110. Bøhn SK, Blomhoff R, Paur I. Coffee and cancer risk, epidemiological evidence, and molecular mechanisms. Mol Nutr Food Res 2014;58:915-30. DOI PubMed

111. Farinati F, Cardin R, Degan P, et al. Oxidative DNA damage in circulating leukocytes occurs as an early event in chronic HCV infection. Free Radic Biol Med 1999;27:1284-91. DOI PubMed

112. Farinati F, Cardin R, Bortolami M, et al. Hepatitis C virus: from oxygen free radicals to hepatocellular carcinoma. $J$ Viral Hepat 2007;14:821-9. DOI PubMed

113. Piciocchi M, Cardin R, Cillo U, et al. Differential timing of oxidative DNA damage and telomere shortening in hepatitis C and B virus-related liver carcinogenesis. Transl Res 2016;168:122-33. DOI PubMed

114. Poli G. Pathogenesis of liver fibrosis: role of oxidative stress. Mol Aspects Med 2000;21:49-98. DOI PubMed

115. Shaposhnikov S, Hatzhol T, El Yamani N, et al. Coffee and oxidative stress: a human intervention study. Eur J Nutr 2018;57:533-44. DOI PubMed

116. Cardin R, Piciocchi M, Martines D, Scribano L, Petracco M, Farinati F. Effects of coffee consumption in chronic hepatitis C: a randomized controlled trial. Dig Liver Dis 2013;45:499-504. DOI PubMed

117. Pal S, Polyak SJ, Bano N, et al. Hepatitis C virus induces oxidative stress, DNA damage and modulates the DNA repair enzyme NEIL1. J Gastroenterol Hepatol 2010;25:627-34. DOI PubMed PMC

118. Farinati F, Cardin R, De Maria N, et al. Iron storage, lipid peroxidation and glutathione turnover in chronic anti-HCV positive hepatitis. J Hepatol 1995;22:449-56. DOI PubMed

119. Bortolami M, Kotsafti A, Cardin R, Farinati F. Fas/FasL system, IL-1beta expression and apoptosis in chronic HBV and HCV liver disease. J Viral Hepat 2008;15:515-22. DOI PubMed

120. Farinati F, Cardin R, Bortolami M, Guido M, Rugge M. Oxidative damage, pro-inflammatory cytokines, TGF-alpha and c-myc in chronic HCV-related hepatitis and cirrhosis. World J Gastroenterol 2006;12:2065-9. DOI PubMed PMC

121. Chuma M, Hige S, Nakanishi M, et al. 8-Hydroxy-2'-deoxy-guanosine is a risk factor for development of hepatocellular carcinoma in 
patients with chronic hepatitis C virus infection. J Gastroenterol Hepatol 2008;23:1431-6. DOI PubMed

122. Oikawa S, Kawanishi S. Site-specific DNA damage at GGG sequence by oxidative stress may accelerate telomere shortening. FEBS Letters 1999;453:365-8. DOI PubMed

123. Artandi SE, DePinho RA. Telomeres and telomerase in cancer. Carcinogenesis 2010;31:9-18. DOI PubMed PMC

124. Farinati F, Cardin R, Fiorentino M, et al. Imbalance between cytoproliferation and apoptosis in hepatitis $\mathrm{C}$ virus related chronic liver disease. J Viral Hepat 2001;8:34-40. DOI PubMed

125. Farinati F, Cardin R, Bortolami M, Rugge M. Up and down regulation of apoptosis in hepatitis C virus-related liver damage. $J$ Hepatol 2004;41:883-5; author reply 885. DOI PubMed

126. Lopez-Garcia E, van Dam RM, Qi L, Hu FB. Coffee consumption and markers of inflammation and endothelial dysfunction in healthy and diabetic women. Am J Clin Nutr 2006;84:888-93. DOI PubMed

127. Shin JW, Wang JH, Kang JK, Son CG. Experimental evidence for the protective effects of coffee against liver fibrosis in SD rats. $J$ Sci Food Agric 2010;90:450-5. DOI PubMed

128. Calin GA, Croce CM. MicroRNA signatures in human cancers. Nat Rev Cancer 2006;6:857-66. DOI PubMed

129. Romualdo GR, Prata GB, da Silva TC, et al. The combination of coffee compounds attenuates early fibrosis-associated hepatocarcinogenesis in mice: involvement of miRNA profile modulation. J Nutr Biochem 2020;85:108479. DOI PubMed

130. Catalano D, Martines GF, Tonzuso A, Pirri C, Trovato FM, Trovato GM. Protective role of coffee in non-alcoholic fatty liver disease (NAFLD). Dig Dis Sci 2010;55:3200-6. DOI PubMed

131. Gutiérrez-Grobe Y, Chávez-Tapia N, Sánchez-Valle V, et al. High coffee intake is associated with lower grade nonalcoholic fatty liver disease: the role of peripheral antioxidant activity. Ann Hepatol 2012;11:350-5. PubMed

132. Michelotti GA, Machado MV, Diehl AM. NAFLD, NASH and liver cancer. Nat Rev Gastroenterol Hepatol 2013;10:656-65. DOI PubMed

133. Bucci L, Garuti F, Lenzi B, et al; Italian Liver Cancer (ITA. LI.CA) group. The evolutionary scenario of hepatocellular carcinoma in Italy: an update. Liver Int 2017;37:259-70. DOI PubMed 